\title{
Technology Management: A Cross-Disciplinary Master-Program with a Focus on Leadership
}

\author{
Charlotta Johnsson ${ }^{1}$, Carl-Henric Nilsson ${ }^{2} \&$ Stein Kleppesto ${ }^{2}$ \\ ${ }^{1}$ Faculty of Engineering, Lund University, Lund, Sweden \\ ${ }^{2}$ Economics and Management, Lund University, Lund, Sweden \\ Correspondence: Carl-Henric Nilsson, Economics and Management, Lund University, Lund, Sweden. E-mail: \\ carl-henric.nilsson@fek.lu.se
}

Received: October 9, 2016

Accepted: October 12, 2016 Online Published: October 26, 2016

doi:10.5539/emr.v5n2p40

URL: http://dx.doi.org/10.5539/emr.v5n2p40

\begin{abstract}
Leadership is important. Management is important. There are good reasons to conceptually and pedagogically separate the two in order to see some fundamental differences. In a cross disciplinary master program named Technology Management at Lund University, Sweden, the students are given opportunities to study and learn management, and however, what makes the program unique is its profound focus on leadership. The Technology Management program includes six courses, Teamwork and Leadership being one of them. In this course, theories and knowledge in leadership is learnt and discussed, this is then intertwined into the other courses in which it is practiced, and finally the outcome is brought back to the Teamwork and Leadership course for further discussions. In addition to this the students are writing daily reflections in a so called Learning Journal, over a one-year period, making it possible for the students to reflect over and thereby shape their own leadership style and mindset. Course evaluations and placement reports indicates that the students learning about theories, practice and mindset related to leadership is ranked as the most valuable learning from their entire educational curricula/period.
\end{abstract}

Keywords: leadership, leadership development, technology management, higher education

\section{Introduction}

Since many years we have seen an on-going debate on the merits of conceptually separating management and leadership (Kotter, 1990; Mintzberg, 2009). In management, the focus is on planning, organizing, maintaining and administrating work related activities. In leadership, the focus is on inspiring, innovating, developing, and leading people in relationship related activities.

Students, in engineering or business, with an interest in understanding the interplay between technology, business and people, can apply to a 2-year master program named Technology Management at Lund University, Sweden. The program, initiated in 1997, includes opportunities to study and learn management, however, what makes the program unique is its profound focus on leadership. It is believed that management alone is not enough for tomorrow's industry and business executives, leadership skills are becoming increasingly important. The belief is also that leadership can be taught and learnt in academic programmes, provided that the students have an individual interest in leadership, group dynamics and personal development. Learning opportunities are provided to the students, but a successful result can only be achieved with a great portion of commitment from the student, the hard work has to be done by each and every individual.

The paper starts with a general discussion about the concepts of management and leadership (chapter 2) and argues that both skills are needed by tomorrow's industrial and business executives. However, the focus on leadership is often left out in traditional management educations. There after aspects of teaching and learning leadership are discussed (chapter 3) and the Technology Management programme is outlined (chapter 4 and 5). Special focus is given to the course named teamwork-and-leadership, which is described in more detail because of its strong focus on teaching and learning leadership. Students' feedback on this course is also presented as well as feedback on the complete program from alumni and future employers (chapter 6). After graduation, more than $95 \%$ of the students leave academia and head to various positions in industry, their feedback is the ultimate proof of the programme's relevance. The ultimate goal of Technology Management - a master program with a focus on leadership-is to prepare the students with theories, skills and a mindset that make them well equipped 
for taking on leading roles in industry after their graduation.

\section{Leadership and Management}

Peter Drucker (1959) argues that there might have been a time when a foreman in an industrial-era factory probably didn't have to give much thought to what he or she was producing or to the people who were producing it. His or her job was to follow orders, organize the work, assign the right people to the necessary tasks, coordinate the results, and ensure the job got done as ordered. The focus was on efficiency (Wall Street Journal, 2009). Peter Drucker also argues that in the new economy, where value comes increasingly from the knowledge of people, and where workers are no longer undifferentiated cogs in an industrial machine, management and leadership are not easily separated. People look to their managers, not just to assign them a task, but to define for them a purpose. And managers must organize workers, not just to maximize efficiency, but also to nurture skills, develop talent and inspire results (Wall Street Journal, 2009).

Peter Drucker introduced the concept of Knowledge workers 1957 (Drucker, 1959). Knowledge workers are workers whose main capital is knowledge. Typical examples may include software engineers, doctors, architects, engineers, scientists, public accountants, lawyers, and academics, because they "think for a living" (Davenport, 2005). What differentiates knowledge work from other forms of work is its primary task of "non-routine" problem solving that requires a combination of convergent, divergent, and creative thinking (Reinhardt et al., 2011). This indicates that leadership skills are becoming increasingly more valuable and management skills alone are not enough.

As pointed out by Michael Maccoby, management is a function that must be exercised in any business, leadership is a relationship between leader and led that can energize an organization (Maccoby, 2000). In the list below, some of the differences between management and leadership are pointed out (Bennis, 1989):

1) The manager maintains; the leader develops.

The manager focuses on systems and structure; the leader focuses on people.

2) The manager relies on control; the leader inspires trust.

3) The manager has a short-range view; the leader has a long-range perspective.

4) The manager asks how and when; the leader asks what and why.

5) The manager has his or her eye always on the bottom line; the leader's eye is on the horizon.

6) The manager imitates; the leader originates.

7) The manager accepts the status quo; the leader challenges it.

8) The manager is the classic good soldier; the leader is his or her own person.

9) The manager does things right; the leader does the right thing.

In the future, knowledge workers will be increasingly important, generating value and profit for companies. Hence, for future foremen and executives, management skills alone are not enough but needs to be complemented with a profound understanding in leadership.

\section{Teaching and Learning Leadership}

Today there is an increased focus in trying to understand the mindset of successful leaders (Llopis, 2013; Myatt, 2012), and the underpinning question of whether or not leadership can be learnt, i.e., can students learn to become leaders? Can mindset be learnt?

In general, traditional pedagogical approaches in teaching and learning are centred on theory and practice alone, whereas the mindset part is often left out. New results in psychology states that people with a growth mindset see their qualities as things that can be developed through their dedication and effort (Dweck, 2006). In a proposed new pedagogical approach, called Mindset-methodology (Johnsson, Loeffler, Sidhu, \& Nilsson, 2015), see Figure 1, activities centred on the mindset of the students are added to those centred on theories and practice, student engagement is a prerequisite. By including aspects related to mindset in teaching and learning activities, students can get help to understand the mindset of successful leaders and to tune their own mindset. The proposed new pedagogical approach is student-centric and has an iterative action-reflection approach. It has been applied to the leadership curriculum Technology Management, with positive outcome (Johnsson, Nilsson, Erlingsdottir, Nilsson, \& Alsén, 2013). A similar approach has also been applied to education in Entrepreneurship (Sidhu, Singer, Suoranta, \& Johnsson, 2014). Like leadership, entrepreneurship is a community with its own culture, and understanding the mindset of successful entrepreneurs is vital. 


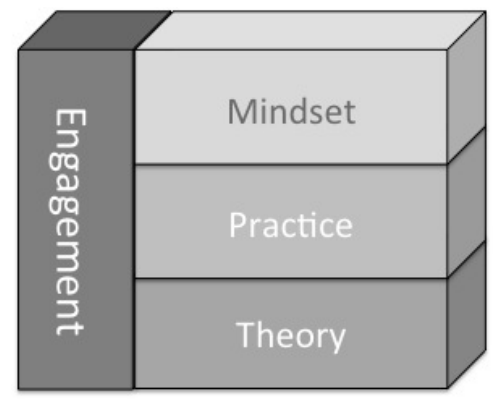

Figure 1. The four building blocks of MINDSET-methodology

To teach and educate future leaders (as well as entrepreneurs) is orthogonal to traditional teaching in respect to how teaching is conducted by the instructors/teachers. An instructor that wants to educate future leaders and innovators should, e.g., lead from the side as opposed to lead from the top, should inspire as opposed to direct, should trust and delegate instead of check and control, should treat the group members as colleagues and not as a subordinate, etc. (Mery, 2014). This is unconventional in teaching and learning situations and calls for a different mindset of the instructor. The instructor should have a mindset that resembles that of a leader, not a manager. It is essential that the students be exposed to this mindset if they themselves want to become leaders. The instructors are also role models.

Leadership is included in the Technology Management program. The program, includes opportunities to study and learn management, however, what makes the program unique is its profound focus on leadership. With such skills the students are well equipped for taking on leading roles in industry after their graduation. The course "Teamwork and Leadership" includes many activities related to leadershipas well as the mindset of leaders.

\section{Introducing the Technology Management Master Program}

Academia traditionally offers, on the one hand, people with a deep knowledge of management and business but lacking an understanding of the underlying technologies and, on the other hand, engineers with a thorough understanding of technology but with limited knowledge about business. Students, in engineering or business, with an interest in understanding the interplay between technology, business and people, can apply to a 2-year master program named Technology Management at Lund University, Sweden. Each year, 40 students are accepted to the program. The ultimate goal of Technology Management - a master programme with a focus on leadership, is to prepare the students with theories, skills and a mindset that make them well equipped for taking on leading roles in industry after their graduation.

\section{$\because$ \\ TECHNOLOGY \\ MANAGEMIENT}

Figure 2. Technology Management, Lund University, Sweden

The program can be explained by three phases:

Phase I covers the first 3 years of the engineering students' program and the 3 years of a bachelor's education for the business administration students.

Phase II prepares the engineering students with rudimentary knowledge of business administration, management and economics, and the business administration students with a basic knowledge of technology and engineering. This is done by letting the business students attend a selected number of courses in technology, and engineering students in courses in management and business. In addition to this, specific courses for the Technology Management students begin. In these courses, the students are working side-by-side, engineering students and 
business students, giving ample room for understanding each other's way of thinking and working and to start learning about leadership.

Phase III is the fully integrated conclusion of the program with courses plus a 6-month master's thesis. During Phase III, the students continue to work side-by-side. The students find means of utilizing each other's differences in skills and interests and turn the differences into advantages instead of being obstacles for co-operation. The Technology Management specific courses in Phase II and III are designed to include engineering and management aspects as well as a large portion of leadership. The participating teachers in a course come from different faculties, and cooperate in the joint teaching of the course. The master's thesis is performed during a 6-month period by a group of two to three students with at least one student from each faculty.

A schematic outline of the Technology Management program is shown in Figure 3.

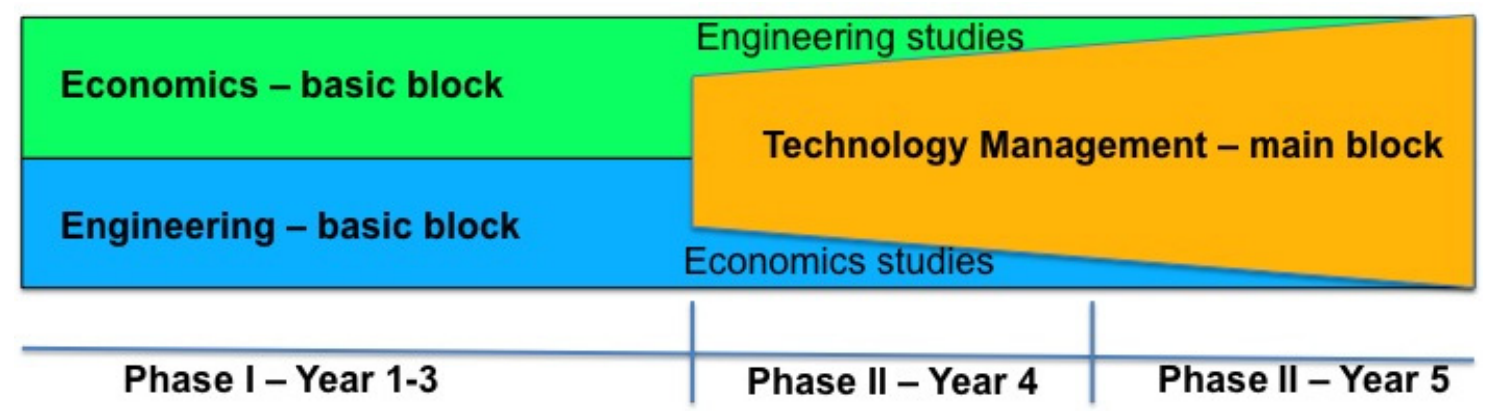

Figure 3. Schematic outline of Technology Management program

After concluding the program, the students are awarded a master's degree depending on their academic point of origin. For the engineering students this will be a "Master of Science in XX (engineering subject) with Technology Management". For the Business administration students this will be a "Master of Science (120 credits) with major in Technology Management".

There are six specific courses included in Phases II and III. The courses have varied slightly over the years, the current courses are: Project Leadership (PL), Technology, Strategies and Structures (TSS), International Market-Driven Engineering (IMDE), Global Technology Exploration (GTE), Project in Technology Management (PTM-Kaos), Teamwork and Leadership (ToL) and Master Thesis (exjobb), see Figure 4.

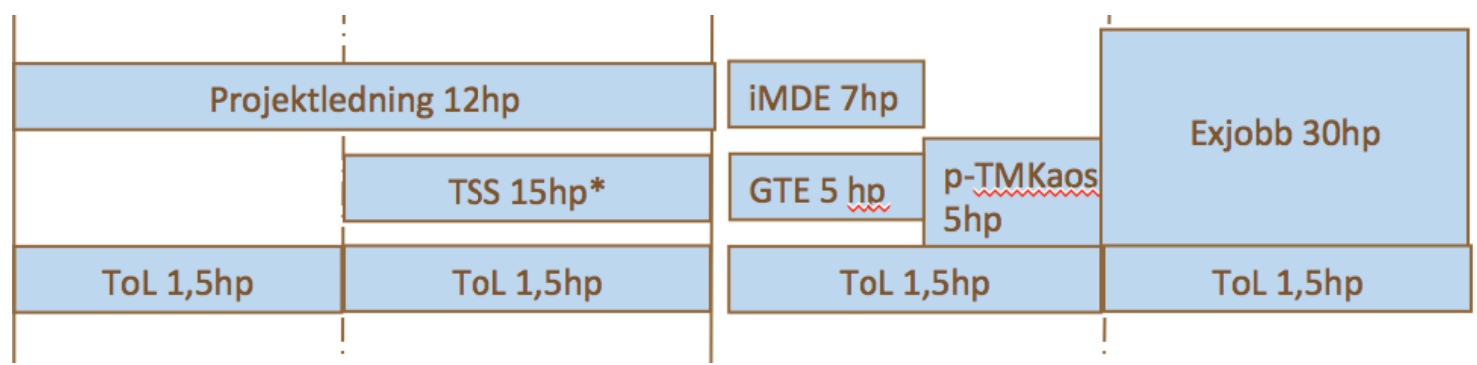

Figure 4. Schematic outline of the Technology Management (main block) including 6 courses and a master thesis

In all courses, except the master thesis project, the students are working in groups of five, including students from both faculties. The course Teamwork and Leadership (ToL) stretches throughout the two-year program and provides the students with knowledge and tools related to leadership. The students' new leadership skills can be applied directly in the group work done in other courses, and feedback on the outcome is brought back to the Teamwork and Leadership course where it is reflected upon. In this way, practicing of leadership is included in all technology management courses, as briefly described below:

1) The course Project Leadership (PL) includes one semesterlong project. Each group of 5 is responsible for one project that is carried out in collaboration with an industry company. The project is led by one of the students in 
the group. Feedback from the group regarding the leadership abilities of the project leader is given on a regular basis. The course also includes lectures on leadership.

2) The course Technology, Strategies and Structures (TSS) includes four one-month-long projects. Each group of 5 is responsible for four projects, each one carried out in collaboration with an industry company. Each project is led by one of the students in the group. Feedback from the group regarding the leadership abilities of the project leader is given on a regular basis.

3) The course International Market-Driven Engineering (IMDE) includes a six-week long project. Each group of 5 is responsible for one project, and one student is acting project leader. In this project new external project-members are added to the group and one leadership challenge is to effectively include the new members in the team and to create a positive climate in the new extended group.

4) The course Global Technology Exploration (GTE) includes a six-week long project. Two groups of 5 are merged and one student is acting project leader. In this project, a challenge is to manage a team twice as big as the usual team.

5) The course Project Technology Management (PTM-Kaos) includes a six-week long project. Several teams are working together and one student is acting as project leader. In this project, a challenge is to manage a team several times as big as the usual team. The project is done in collaboration with an external company.

With this arrangement, each student will have the possibility to act as project leader at least once. In the course Teamwork and Leadership, the students are provided with leadership theories and practices and given opportunities to discuss the leadership phenomena, both before and after practicing it in the other courses.

\section{Introducing the Course "Teamwork and Leadership"}

The course Teamwork and Leadership stretches throughout the full 2-year programme. A set of eight distinct activities is included in this course as shown in Figure 5.

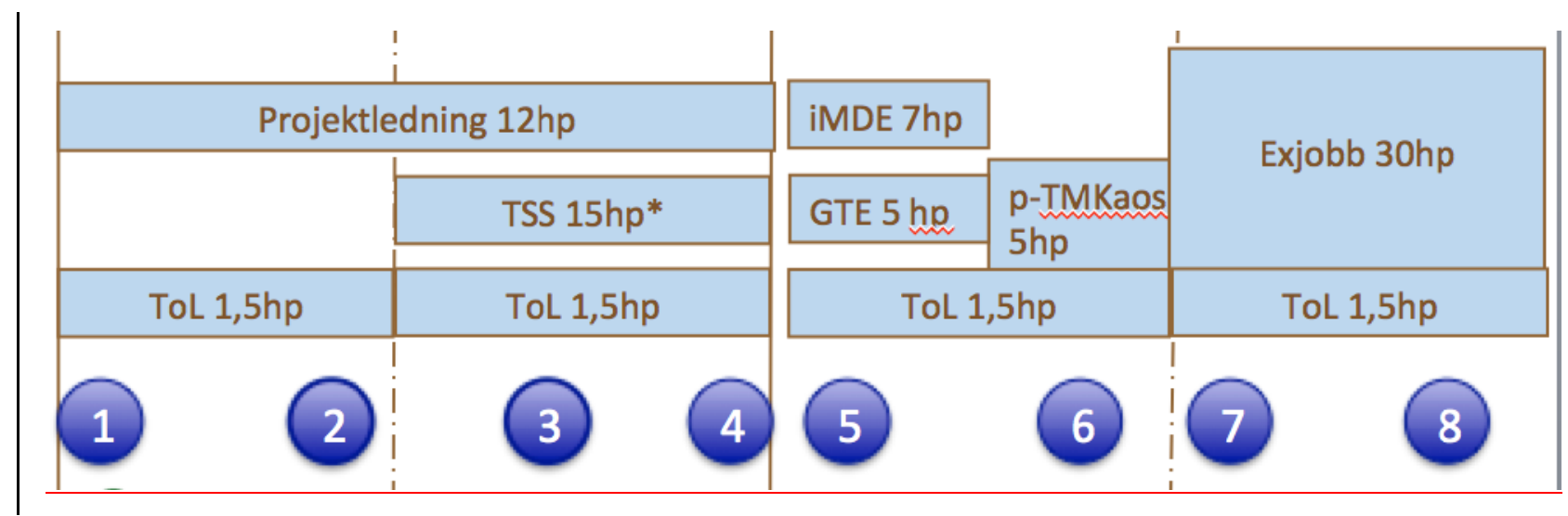

Figure 5. Teamwork and Leadership

The activities (normally 1-2 day long) are:

Mission Impossible: a challenge is given to the group of students. The task is to complete it within 36 hours. Examples of tasks have been to build a new playground to an elementary school, to arrange with an outdoor gym for high-school students, etc.

Feedback: How can one give and accept feedback to/from others.

Outdoor-activity: Various team exercises and discussions about team development and people development.

Communication: Discussions about working in groupswith focus on the importance of communication and how it can be done effectively.

Leader: Discussion about what a leader is.

Leadership: Discussions about what leadership is.

Master thesis: Preparation for the master thesis. What is required from a small team ( 2 or 3 students) working very closely together? 
Work-life: Preparation for the life after graduation and discussion about how one can continue to develop ones owns leadership skills.

These activities include both theoretical aspects and mindset aspects related to leadership. Practicing the leadership skills are done in the other parallel courses. In addition to these activities, the students are documenting their own personal reflections in a so-called Learning Journal (Johnsson et al., 2013). This is done on a daily basis over a period of 1 year. In this way, the students can find their own strengths and weaknesses related to leadership, and can sculpture their own leadership style.

\section{Feedback from Students, Alumni and Employers}

After the completion of a course, the students fill out evaluation forms. The two most important questions are:

- The students' perception of the relevance of the course (Approx. should the course be part of the curriculum?)

- The students' perception of the quality of the course (Approx. Is the course well taught?)

The results are given in a scale from -100 (very bad) to +100 (very good). The course Teamwork and Leadership has over the last years received very high grades from the students. The grades, on each of the two questions, have varied between +98 and +100 . This clearly indicates that the students appreciate this course and that the students are interested in learning about leadership; including theory, practice and mindset aspects.

Further, the students claim that the curriculum helps them grow both as individuals and professionals in a way they would not have done without the mindset activities. Five to ten years after graduation, the students rank the activities focused around leadership, primarily the Teamwork and Leadership course, as the most valuable learning from their entire educational curricula/period (Johnsson et al., 2013).

An entry level salary is partly based on the brand and reputation of a program or a university, whilst the continued salary progression better describes the qualities of the individual. The alumni from the Technology Management program have a steep salary development after graduation. The annual increase in salary has been as high as $8.5 \%$ according to Technology Management Placement Report (2010).

\section{Discussions}

Research traditionally has been viewed as a precursor to education. Research projects are formulated, the hypotheses are examined and answers found, thereafter the findings are included in education, e.g., courses and other activities. In a research application related to leadership and entrepreneurship education, the research is tackled in the opposite way. Student-centred and mindset oriented activities have been incorporated in educational programs and courses for a number of years with successful results. As a consequence, applications for new research projects (e.g., the Berkeley Method of Entrepreneurship, the MINDSET-methodology, and research related to the Technology Management program) have been submitted in order to further explore the field of student-centred and mindset oriented teaching and learning associated with entrepreneurial and leadership education.

\section{Conclusions}

Leadership is important. Management is important. There are good reasons to conceptually and pedagogically separate the two in order to see some fundamental differences. In management, the focus is on planning, organizing, maintaining and administrating work related activities. In leadership, the focus is on inspiring, innovating, developing, and leading people in relationship related activities.

Technology Management is a unique program at Lund University, where a selected number (40) of students from the Faculty of Economics and from the Faculty of Engineering are taught together during their last two years of study. Their degree is Master's degree. The program, includes opportunities to study and learn management, however, what makes the program unique is its profound focus on leadership. The program curriculum consists of is $\mathrm{x}(6)$ courses, project leadership being one of them. The project leadership course includes eight distinct activities related to leadership. In addition, what is taught and learnt in this course is intertwined into the other courses in the program. In this way each student has opportunities to practice and develop his/her own leadership style.

The ultimate goal of Technology Management is to prepare the students with theories, skills and a mindset that make them well equipped for taking on leading roles in industry after their graduation. Student reports, course evaluations and placement reports reveal promising results indicating that the students are interested in, and appreciate, learning about leadership; including both theory, practice and mindset aspects. Knowledge, practice and mindset related to leadership are the ranked as the most valuable learning from their entire educational curricula/period. 


\section{Acknowledgement}

The authors would like to thank the following research centres/organizations for providing financial and/or administrative support as well as for being a source of inspiration; LCCC at Lund University, Sweden, Center for Entrepreneurship and technology at UC Berkeley and Familjen Knut och Ragnvi Jacobssons stiftelse.

\section{References}

Alan, M. (April 7, 2009). What is the Difference Between Management and Leadership? Adapted from "The Wall Street Journal Guide to Management". Wall Street Journal. Harper Business.

Bennis, W. (1989). On Becoming a Leader. New York, NY: Basic Books.

Davenport, T. H. (2005). Thinking for a Living: How to Get Better Performance and Results from Knowledge Workers. Boston, Mass: Harvard Business School Press.

Drucker, P. F. (1959). The Landmarks of Tomorrow. New York: Harper and Row.

Dweck, C. (2006). MINDSET: The new psychology of success. New York, NY: Random House.

Johnsson, C., Loeffler, R., Sidhu, I., \& Nilsson, C. H. (2015). A Student-Centered and Mindset-Focused Pedagogical Approach for Entrepreneurship and Leadership. In American Society for Engineering Education. Seattle.

Johnsson, C., Nilsson, C. H., Erlingsdottir, G., Nilsson, F., \& Alsén, G. (2013). Metacognition and Learning Journals in Higher Education. International Journal of Economics and Management Engineering, 3(4), 152-159.

Kotter, J. P. (1990). A force for change: How Leaders differ from Management. New York, NY: Free Press.

Llopis, G. (2013). The most successful leaders do 15 things automatically, every day. Forbes.

Maccoby, M. (2000). Understanding the Difference Between Management and Leadership. Research Technology Management, 43(1), 57-59.

Mery, N. (2014). Lecture at Engineering Leadership Professional Program. UC Berkeley.

Mintzberg, H. (2009). Managing. San Francisco, CA: Berrett-Koehler.

Myatt, M. (2012). 15 ways to identify bad leaders. Forbes.

Reinhardt, W., Schmidt, B., Sloep, P., \& Drachsler, H. (2011). Knowledge Worker Roles and Actions-Results of Two Empirical Studies. Knowledge and Process Management, 18(3), 150-174. http://dx.doi.org/10.1002/kpm.378

Sidhu, I., Singer, K., Suoranta, M., \& Johnsson, C. (2014). Introducing the Berkeley Method of Entrepreneurship-A game-based teaching approach. In 7th Annual Meeting of the Academy of Management Workshop, Philadelphia PA, USA.

Technology Management Placement Report. (2010).

\section{Copyrights}

Copyright for this article is retained by the author(s), with first publication rights granted to the journal.

This is an open-access article distributed under the terms and conditions of the Creative Commons Attribution license (http://creativecommons.org/licenses/by/4.0/). 